Arq. Bras. Med. Vet. Zootec., v.73, n.5, p.1117-1127, 2021

\title{
Morphology and molecular phylogeny of Heterobothrium lamothei (Monogenea: Diclidophoridae), a gill parasite infecting the tiger puffer fish Lagocephalus sceleratus (Tetraodontidae)
}

\begin{abstract}
[Morfologia e filogenia molecular de Heterobothrium lamothei (Monogenea: Diclidophoridae), um parasita das guelras que infecta o peixe tigre pufferLagocephalus sceleratus (Tetraodontidae)]
\end{abstract}

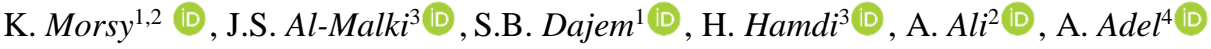 \\ ${ }^{1}$ Biology Department, College of Science, King Khalid University, Abha, Saudi Arabia \\ ${ }^{2}$ Zoology Department, Faculty of Science, Cairo University, Cairo, Egypt \\ ${ }^{3}$ Department of Biology, College of Science, Taif University, P.O. Box 11099, Taif 21944, Saudi Arabia \\ ${ }^{4}$ Zoology Department, Faculty of Science, South Valley University, Qena, Egypt
}

\begin{abstract}
Members of the family Diclidophoridae are potentially dangerous species for the puffer fish aquaculture worldwide. They are parasitic polyopisthocotyleans, with a posterior haptor equipped with clamps for attachment to the host's surface, allowing the worm to resist the flow of water to maintain its position on gills. The anterior body of the worm is deformable, allows the worm to feed on blood sucked from fish gills. The present study is the first description of a Heterobothrium species from the gills of the tiger puffer Lagocephalus sceleratus (Tetraodontidae) from the coasts of the Arabian Gulf at Jubail, Saudi Arabia morphologically by light microscopy as well as by molecular analysis of the parasite partial 28S rRNA through multiple sequence alignments and phylogeny by maximum likelihood analysis which is provided for the first time for the described species. Seventeen tiger puffer fish were captured alive from marine water off Saudi Arabia; gills were separated and further examined for parasitic infection. Nine fish were found infected with a monogenean parasite which was robust, equipped by two buccal organs at the tapered anterior end; the posterior haptor was rectangular with four symmetrically arranged clamps, with no isthmus. Marginal hooks absent. Ovary elongated, U-shaped, testes numerous, irregularly shaped and extended from the posterior part of the ovary to the anterior margin of the haptor. Copulatory organ muscular, as a spherical cup armed with 12 to 15 genital hooks. The molecular analysis of the parasite 28s rRNA and phylogeny revealed a percentage of identities between 87.47-89.09\%, with Diclidophoridae species within the monophyletic clade of Mazocraeidea where a maximum percentage of $89.09 \%$ were obtained for the morphologically different sister taxon H. okamotoi. The results obtained from molecular analysis are consistent with the conclusions drawn from morphological classification where that the parasite recorded was morphologically similar to H. lamothei which was not characterized by molecular analysis before. The recovered sequences were deposited into the GeneBank under accession number MT322610.
\end{abstract}

Keywords: Diclidophoridae, Heterobothrium, morphology, molecular study, puffer fish

\section{RESUMO}

Os membros da família Diclidophoridae são espécies potencialmente perigosas para a aquicultura de peixes puffer em todo o mundo. Eles são parasitas poliopisthocotyleans, com uma hélice posterior equipada com pinças para fixação na superfície do hospedeiro, permitindo que o verme resista ao fluxo de água para manter sua posição nas brânquias. O corpo anterior do verme é deformável, e permite que o verme se alimente de sangue sugado das guelras dos peixes. O presente estudo é a primeira descrição de uma espécie Heterobothrium das guelras do tigre Lagocephalus sceleratus (Tetraodontidae) das costas do Golfo Arábico em Jubail, Arábia Saudita, usando morfologia por microscopia leve, bem como análise molecular do rRNA parcial do parasita $28 S$ através de alinhamentos de sequências múltiplas e filogenia por análise de máxima verossimilhança que é fornecida pela primeira vez para as espécies descritas. Dezessete peixes tigre puffer foram capturados vivos da água marinha da Arábia Saudita; as brânquias foram separadas e mais tarde examinadas para detecção de infecção parasitária. Nove peixes foram encontrados infectados por um parasita monogênio robusto, equipado por dois órgãos bucais na extremidade anterior afilada; o hortetor posterior era retangular com quatro pinças dispostas simetricamente, sem istmo. Ausência de ganchos marginais. Ovário alongado, em forma de U, testículos numerosos, de forma irregular e estendido desde a parte posterior do ovário até a margem anterior do hortelino. Órgão copulatório muscular, como um copo esférico armado com 12 a 15 ganchos genitais. A análise molecular do parasita $28 s$ rRNA e filogenia revelou uma porcentagem de identidades entre 87,47-89,09\%, com espécies Diclidophoridae dentro do clade monofilético de Mazocraeidea onde uma porcentagem máxima de 89,09\% foi obtida para o táxon-irmão

Corresponding author: kareemsaid156@yahoo.com

Submitted: January 20, 2021. Accepted: June 11, 2021. 
morfologicamente diferente $H$. okamotoi. Os resultados obtidos da análise molecular são consistentes com as conclusões tiradas da classificação morfológica onde o parasita registrado era morfologicamente semelhante ao $H$. lamothei que não era caracterizado pela análise molecular antes. As sequências recuperadas foram depositadas no GeneBank sob o número de acesso MT322610.

Palavras-chave: Diclidophoridae, Heterobotrium, morfologia, estudo molecular, peixe puffer

\section{INTRODUCTION}

Monogeneans are a group of ectoparasitic flatworms commonly found on the skin, gills, or fins of fish. They have a direct life cycle and do not require an intermediate host. The marine forms of these parasites are generally larger than those found on freshwater hosts. Monogenea have an unusual mode of attachment, in which the haptor and the long muscular pre-haptoral stalk of the adult worms are embedded subcutaneously into the gill arch, leaving only the anterior body of the parasite visible externally, causing severe damage to the host gills (Agrawal et al., 2006). The genus Heterobothrium Cerfontaine (1895) of family Diclidophoridae Sproston (1946), is highly specific to tetraodontid fishes (Actinopterygii: Tetraodontidae), including 11 blood-feeding species of monogeneans infecting the gills (Williams, 1986; Ogawa, 1997) with high species diversity and host specificity (Boeger and Kritsky, 2001; Desdevises et al., 2002; Šimkova et al., 2006). Immature worms of these parasites attach to the gill filaments of their hosts, feeding on the blood, causing impaired breathing and anemia to their hosts, and then migrate to the buccal cavity wall for maturation (Matsui et al., 2020). They cause serious problems and a high mortality rate in aquaculture of puffer fish worldwide (Yoshinaga et al., 2001; Nakayasu et al., 2002; Nakane et al., 2005). Goto, in 1894, described Diclidophora tetrodonis Goto (1894) from Tetraodon sp. stating that its peculiar characteristic was the reverse orientation of the anterior most clamp pair compared to the other pairs. Cerfontaine (1895) considered that this species should be allocated to a distinct genus, Heterobothrium, with H. tetrodonis as the type species (Nagibina 1953). Phylogenetically, diclidophorids are considered an ancient group, and one of the most predominant families of deep-sea monogeneans (Justine et al., 1985; Rohde, 1988). Compared to morphology, phylogeny provides more reliable information regarding evolutionary relationships (Scotland et al., 2003; Pandey and Agarwal, 2008). Lagocephalus sceleratus Gmelin (1789), commonly known as the silver-cheeked toadfish, is an extremely poisonous marine bony fish in the family Tetraodontidae (puffer fishes) distributed in many habitats including the Arabian Gulf of Saudi Arabia. The ancient pharaohs identified puffer fish and draw them on their tombs because of its importance, due to it carrying the very famous alkaloid toxin, Tetrodotoxin (TTX) (Mohammed-Geba et al., 2016). The present study is the first description of a Heterobothrium species from the tetraodontid L. sceleratus from coasts of the Arabian Gulf at Jubail, Saudi Arabia morphologically by light microscopy as well as molecular analysis of the parasite partial 28S rDNA which is provided for the first time for the recovered species.

\section{MATERIALS AND METHODS}

Fish and parasite sampling: A total of 17 specimens of tiger puffer fish L. sceleratus (Tetraodontidae) were collected alive from local fishermen along the coasts of the Arabian Gulf at Jubail $\left(26.9598^{\circ} \mathrm{N}, 49.5687^{\circ} \mathrm{E}\right)$, Saudi Arabia, between January and May 2019. The fish were morphologically identified according to the guidelines of Randall (1995). Following capture, fish were euthanized by means of percussive stunning followed by severing the spinal cord immediately posterior to the brain. After removing the opercula and exposing the gill arches, the gills were removed carefully from the fish and placed in Petri dishes with tap water, and then examined by a stereomicroscope for the presence of monogeneans (Mendoza-Franco et al., 2018). Worms were collected from the gill filaments with the aid of a fine brush and fixed with hot water $\left(60^{\circ} \mathrm{C}\right)$. Some specimens were stored in a mixture of ammonium picrate glycerin (GAP) (Ergens, 1969), and some in hot $4 \%$ formalin for morphological analysis, while some worms were fixed in $70 \%$ ethanol for molecular analyses.

Morphological analyses: some worm specimens were stained in Semichon's carmine and dehydrated in series of ethanol (staining for $2 \mathrm{~min}$; cleaning in $70 \%$ ethanol for $\sim 1 \mathrm{~min}$; destaining in $1 \% \mathrm{HCl}$ solution for $\sim 2 \mathrm{~min}$ or 
until the inner structures were differentiated; dehydration in 80,90 , and $100 \%$ ethanol for $\sim 2 \mathrm{~min}$; clearing in clove oil for $\sim 2 \mathrm{~min}$ ) and mounted in Canada Balsam. Unstained specimens were flattened with coverslips on slides with a mixture of ammonium picrate glycerin to study the morphology of the sclerotized structures and remounted in Canada Balsam (Ergens 1969). Terminology and nomenclature of the clamp sclerites were determined according to the key published by Vidal-Martínez and Mendoza-Franco (2008) for Diclidophoridae. Photomicrographs were taken with a BX53 microscope (Olympus Corporation, Japan). Illustrations were made by camera lucida. Measurements were expressed in micrometers $(\mu \mathrm{m})$ as a mean \pm Standard deviation followed by the range in parentheses.

Molecular study: From 70\% ethanol-preserved samples, genomic DNA (gDNA) was extracted from the recovered worms using a DNeasy tissue kit (Qiagen, Germany), following the manufacturer's instructions. PCR amplification of a partial 28s rRNA sequence was carried out on an MJ Research PTC-150 thermocycler (Marshall Scientific, USA) using the internal primers Halio-F 5'ACCCGCTGAATTTAAGCAT-3' and Halio-R 5'-TGGTCCGTGTTTCAAGAC-3' (GarcíaVásquez et al., 2015). All PCR reactions were performed in a final volume of $50 \mu \mathrm{L}$, composed of $5 \mu \mathrm{L} 10 \times$ PCR buffer, $1.5 \mu \mathrm{L} 10 \mathrm{mM}$ deoxynucleoside triphosphate mixture (dATP, dCTP, dGTP, and dTTP, $10 \mu \mathrm{M}$ each), $4.0 \mu \mathrm{L}$ $2.0 \mathrm{mM} \mathrm{MgCl} 2,1.5 \mu \mathrm{L}$ of each primer $(10 \mu \mathrm{M})$, $5 \mu \mathrm{L}$ template DNA, $0.24 \mu \mathrm{L}$ of Thermus aquaticus (Taq) DNA polymerase (1.2 units), and $31.26 \mu \mathrm{L}$ of nuclease-free sterile doubledistilled water. The following thermocycling profile was used: initial denaturation at $94^{\circ} \mathrm{C}$ for $2 \mathrm{~min}$, followed by 35 cycles of $94^{\circ} \mathrm{C}$ for $30 \mathrm{sec}$, annealing at $55^{\circ} \mathrm{C}$ for $30 \mathrm{sec}$, and a final extension at $72^{\circ} \mathrm{C}$ for $3 \mathrm{~min}$ (García-Vásquez et al., 2015).

Phylogenetic analysis: Sequence identity for the recovered data was checked using the Basic Local Alignment Search Online Tool (BLAST, https://blast.ncbi.nlm.nih.gov/Blast.cgi). The sequence trimming for the congeneric species recovered was carried out by Bioedit v7.2.5. The 28 s rRNA sequences obtained were aligned with those of the other monogenean species using CLUSTAL W v.2.0. The phylogenetic tree was constructed using the MEGA v. 7 program, based on maximum likelihood analysis. The genetic divergence among species was estimated using the uncorrected " $p$-distances" method, using the same program.

\section{RESULTS}

Heterobothrium lamothei Vidal-Martinez and Mendoza-Franco (2008) Monogenea;

Diclidophoridae; Mazocraeidea; Parapedocotylinae. Diagnosis: Worms were recovered from the gill filaments as well as the wall of the branchial cavity of the host fish. They were always found grasping the gill filaments using their clamps, with the haptor embedded in the host tissue. Most of the infected fish had very pale gills, with massive mucous secretions.

Light microscopy: Body elongate, robust, tapered anteriorly (Fig. 1a, b), with a mouth opening between the two buccal organs (Fig. 1c). Posterior end of the worm was broad, including a sclerotized haptor which was continuous with the rest of the body, no isthmus was observed (Fig. 1d). The total body length including haptor was 3211 (2095-4354) $\mu \mathrm{m}$, while the greatest width at the ovarian level was $401(328-530) \mu \mathrm{m}$. Paired buccal organs $85 \pm 2 \mu \mathrm{m}$ in diameter $(75-$ $100 ; n=5)$ were observed, pharynx $91 \pm 15(75-$ $110 ; n=5) \mu \mathrm{m}$ in diameter. Intestinal bifurcation was at the level of the gonopore, while lateral and median diverticula of caeca extended to the anterior margin of the haptor. Haptor was rectangular with four symmetrically arranged clamps (Fig. 1d-f). The diameter of the first pair of clamps (anterior-most) was $175 \pm 5$ (160-190; $\mathrm{n}=5) \mu \mathrm{m}$; the second pair was $187 \pm 4(150-$ 220) $\mu \mathrm{m}$; the third pair was $1080 \pm 5$ (155-210) $\mu \mathrm{m}$, while the fourth pair was $168 \pm 5(118-198)$ $\mu \mathrm{m}$. Marginal hooks absent. Testes numerous 23-30 in number, they were irregularly shaped, and extended from the posterior part of ovary to the anterior margin of the haptor. The copulatory organ muscular, as a spherical cup and armed with 12 to 15 genital hooks, $80 \pm 9(80-90 ; n=$ 5) $\mu \mathrm{m}$ in diameter (Fig. 1g). Gonopore midventral. Ovaries elongated and U-shaped, $310 \pm 4(250-370 ; \mathrm{n}=5) \mu \mathrm{m}$ long $\mathrm{x} 181 \pm 3$ $(150-230 ; n=6) \mu \mathrm{m}$ wide and located in front of the testes. The oviduct ran along the left with the genito-intestinal canal passed from the right intestinal limb, connected posteriorly with a vitelline duct followed by the ootype. The uterus was narrow, with only a few eggs. There was no vagina, but there was a genital pore in front of the male organ. The vitelline reservoir was 
situated to the right of the ovary, with follicles scattered from the level of gonopore to the anterior margin of the haptor. Eggs were ovoid, fusiform, and operculated, with long posterior filaments (Figure 1y, j). Figure 2 presents a line diagram illustrating the different morphological diagnostic characteristics of the recovered parasite.

Molecular study: Sequence alignment for the data obtained from 18s rRNA analysis of the monogenean parasite isolated from the host examined yielded $1750 \mathrm{bp}$ aligned with 29 species of Mazocraeidea and Diclybothriidea taxa, recovered after BLAST, with the estimates of evolutionary divergence between sequences calculated (Tables 1 and 2). The constructed phylogenetic tree (Fig. 3) showed that the maximum likelihood analysis of all datasets resulted in Mazocraeidea forming a monophyletic clade. Within this clade, four strongly supported subclades were demonstrated. Sub-clade A includes Diclidophoridae species, sub-clade B includes the mazocraeid species belonging to the families Protomicrocotylidae, Gastrocotylidae, Thoracocotylidae and Gotocotylidae, sub-clade $\mathrm{C}$ includes species of Plectanocotylidae, and sub-clade D includes species belonging to the families Diplozoidae, Discocotylidae, Microcotylidae, Gastrocotylidae and Heteraxinidae. The sequence data of the present parasite was included within the phylogenetic tree between members of the Diclidophoridae species (sub-clade A), with the percentage of identities falling between 87.47$89.09 \%$. The sequence alignment of the parasite recorded showed identities of $86.66 \%, 86.87 \%$, $87.47 \%, 87.50 \%, 87 \%, 50 \%$, and $88.52 \%$ for Neoheterobothrium hirame, Neoheterobothrium sp., Choricotyle australiensis, Diclidophora minor, Diclidophora denticulate, and Bravocotyle sp., respectively, and showed a percentage of $89.09 \%$ for the sister taxon $H$. okamotoi isolated from the puffer fish Takifugu spp.

Table 1. Parasite species used in the sequence alignment as well as phylogenetic analysis of the $H$. lamothei isolated in the current study. 28S rRNA sequences of the parasite isolated were aligned with 29 species of Mazocraeidea and Diclybothriidea taxa, recovered after BLAST. It was shown that the sequences recorded identities of $87.47-89.09 \%$ with species within family Diclidophoridae

\begin{tabular}{|c|c|c|c|c|}
\hline Species & Accession no. & Order & Family & \% Identity \\
\hline Diclidophora minor & AF382070.1 & Mazocraeidea & Diclidophoridae & $87.47 \%$ \\
\hline Choricotyle australiensis & AF382069.1 & Mazocraeidea & Diclidophoridae & $87.50 \%$ \\
\hline Neoheterobothrium hirame & AB 162424.1 & Mazocraeidea & Diclidophoridae & $86.66 \%$ \\
\hline Bravocotyle sp. & КT267179.1 & Mazocraeidea & Diclidophoridae & $88.52 \%$ \\
\hline Neomicrocotyle pacifica & AJ228787.1 & Mazocraeidea & Protomicrocotylidae & $86.28 \%$ \\
\hline Neomicrocotyle pacifica & AJ228787.1 & Mazocraeidea & Protomicrocotylidae & $86.12 \%$ \\
\hline Pseudaxine trachuri & AM157196.1 & Mazocraeidea & Gastrocotylidae & $86.08 \%$ \\
\hline Paradewesia sp. & $\mathrm{AJ} 287555.1$ & Mazocraeidea & Thoracocotylidae & $86.24 \%$ \\
\hline Mexicotyle sp. & AJ287539.1 & Mazocraeidea & Thoracocotylidae & $86.36 \%$ \\
\hline Plectanocotyle gurnardi & AJ228790.1 & Mazocraeidea & Plectanocotylidae & $85.47 \%$ \\
\hline Eudiplozoon nipponicum & AJ287510.1 & Mazocraeidea & Diplozoidae & $86.26 \%$ \\
\hline Paradiplozoon hemiculteri & KY640614.1 & Mazocraeidea & Diplozoidae & $85.03 \%$ \\
\hline Discocotyle sagittata & AJ287504.1 & Mazocraeidea & Discocotylidae & $87.02 \%$ \\
\hline Microcotylidae sp. & JN602094.1 & Mazocraeidea & Microcotylidae & $86.50 \%$ \\
\hline Microcotyle sp. & KT267180.1 & Mazocraeidea & Microcotylidae & $86.67 \%$ \\
\hline Gastrocotyle sp. & KT267185.1 & Mazocraeidea & Gastrocotylidae & $85.61 \%$ \\
\hline Monaxine formionis & KT267181.1 & Mazocraeidea & Heteraxinidae & $85.83 \%$ \\
\hline Pseudohexabothrium taeniurae & AJ228791.1 & Diclybothriidea & Hexabothriidae & $83.01 \%$ \\
\hline Diclybothrium armatum & KP796254.1 & Diclybothriidea & Diclybothriidae & $83.60 \%$ \\
\hline Paradiclybothrium pacificum & KP796243.1 & Diclybothriidea & Diclybothriidae & $83.55 \%$ \\
\hline
\end{tabular}




\section{Morphology and molecular...}

Table 2. Estimates of Evolutionary Divergence between Sequences, the number of base substitutions per site between sequences is shown. Analyses were conducted using the Maximum Composite Likelihood model. Evolutionary analyses were conducted in MEGA7. The numbers shown represent the genetic divergence between species, column no. 1 showed the genetic distance variation between the present $H$. lamothei and the comparable species of Mazocraeidea and Diclybothriidea taxa, recovered after BLAST. The closest sequences of species to those of the present species showed genetic distances between 0.0681-0.1516 within family Diclidophoridae (the first 7 species). The most similar species is $H$. lamothei with a divergence of 0.0681 which give rise to the significant morphology between the comparable species

\begin{tabular}{|c|c|c|c|c|c|c|c|c|c|c|c|c|c|c|c|c|c|c|c|c|c|c|c|c|c|c|c|c|c|}
\hline $\begin{array}{c}\text { Accession } \\
\text { no. }\end{array}$ & Species & 1 & 2 & 3 & 4 & 5 & 6 & 7 & 8 & 9 & 10 & 11 & 12 & 13 & 14 & 15 & 16 & 17 & 18 & 19 & 20 & 21 & 22 & 23 & 24 & 25 & 26 & 27 & 28 \\
\hline MT322610 & H. lamothei (present) & & & & & & & & & & & & & & & & & & & & & & & & & & & & \\
\hline AB162155.1 & H. okamotoi & 0.0681 & & & & & & & & & & & & & & & & & & & & & & & & & & & \\
\hline KT267179.1 & Bravocotyle sp. & 0.1207 & 70.0442 & & & & & & & & & & & & & & & & & & & & & & & & & & \\
\hline AJ228779.1 & D. denticulata & 0.1480 & 0.0691 & 10.0730 & & & & & & & & & & & & & & & & & & & & & & & & & \\
\hline AB162425.1 & $\begin{array}{l}\text { Neoheterobothrium } \\
\text { sp. }\end{array}$ & 0.1500 & 00.0694 & 40.0764 & 0.0567 & & & & & & & & & & & & & & & & & & & & & & & & \\
\hline AB162424.1 & N. hirame & 0.1516 & 60.0695 & 0.0765 & 0.0567 & 0.0000 & & & & & & & & & & & & & & & & & & & & & & & \\
\hline AF382069.1 & C. australiensis & 0.1504 & 40.0724 & 40.0771 & 0.0504 & 0.0527 & 0.0534 & & & & & & & & & & & & & & & & & & & & & & \\
\hline AF382070.1 & D. minor & 0.1453 & 30.0654 & 40.0680 & 0.0316 & 0.0535 & 0.0536 & 0.0486 & & & & & & & & & & & & & & & & & & & & & \\
\hline AJ287504.1 & D. sagittata & 0.1620 & 0.0846 & 60.0952 & 0.0762 & 0.0770 & 0.0764 & 0.0783 & 0.0725 & & & & & & & & & & & & & & & & & & & & \\
\hline JN602094.1 & Microcotylidae sp. & 0.1633 & 30.0868 & 8.0920 & 0.0758 & 0.0843 & 0.0837 & 0.0772 & 0.0714 & 0.0461 & & & & & & & & & & & & & & & & & & & \\
\hline AJ276424.1 & G. bivagina & 0.1660 & 0.0867 & 70.0903 & 0.0810 & 0.0817 & 0.0812 & 0.0796 & 0.0764 & 0.0623 & 0.0629 & & & & & & & & & & & & & & & & & & \\
\hline KT267180.1 & Microcotyle sp. & 0.1612 & 20.0848 & 0.0927 & 0.0757 & 0.0816 & 0.0804 & 0.0796 & 0.0719 & 0.0467 & 0.0121 & 0.0629 & & & & & & & & & & & & & & & & & \\
\hline KT267178.1 & G. secunda & 0.1663 & 30.0868 & 0.0923 & 0.0849 & 0.0844 & 0.0839 & 0.0823 & 0.0822 & 0.0679 & 0.0679 & 0.0145 & 0.0673 & & & & & & & & & & & & & & & & \\
\hline KT267184.1 & B. carangis & 0.1648 & 80.0856 & 0.0921 & 0.0771 & 0.0762 & 0.0756 & 0.0836 & 0.0759 & 0.0681 & 0.0712 & 20.0358 & 0.0706 & 0.0407 & & & & & & & & & & & & & & & \\
\hline AJ287539.1 & Mexicotyle sp. & 0.1644 & 40.0841 & 0.0914 & 0.0789 & 0.0803 & 0.0805 & 0.0814 & 0.0763 & 0.0646 & 0.0634 & 40.0180 & 0.0622 & 20.0268 & 0.0311 & & & & & & & & & & & & & & \\
\hline AJ287555.1 & Paradewesia sp. & 0.1631 & 10.0828 & 0.0901 & 0.0828 & 0.0817 & 0.0805 & 0.0839 & 0.0801 & 0.0684 & 0.0679 & 0.0245 & 0.0654 & 40.0292 & 20.0275 & 0.0186 & & & & & & & & & & & & & \\
\hline AJ228787.1 & N. pacifica & 0.1668 & 80.0868 & 0.0900 & 0.0790 & 0.0780 & 0.0775 & 0.0841 & 0.0764 & 0.0686 & 0.0724 & 40.0377 & 0.0730 & 0.0425 & 0.0063 & 0.0335 & 50.0305 & & & & & & & & & & & & \\
\hline AJ287510.1 & E. nipponicum & 0.1689 & 90.0926 & 0.1018 & 0.0895 & 0.0868 & 0.0875 & 0.0882 & 0.0868 & 0.0705 & 0.0706 & 0.0848 & 0.0698 & 0.0868 & 0.0805 & 0.0828 & 80.0873 & 30.0804 & & & & & & & & & & & \\
\hline AJ276425.1 & G. secunda & 0.1685 & 50.0882 & 0.0956 & 0.0882 & 0.0871 & 0.0865 & 0.0817 & 0.0842 & 0.0686 & 0.0699 & 0.0139 & 0.0693 & 30.0063 & 30.0414 & 40.0263 & 30.0322 & 20.0432 & 20.0862 & & & & & & & & & & \\
\hline AM157196.1 & P. trachuri & 0.1668 & 80.0874 & 0.0921 & 0.0822 & 0.0857 & 0.0852 & 0.0862 & 0.0816 & 0.0787 & 0.0821 & 0.0535 & 0.0814 & 40.0536 & 60.0353 & 0.0499 & 90.0443 & 30.0395 & 50.0921 & 10.0555 & & & & & & & & & \\
\hline KP796254.1 & D. armatum & 0.2060 & 0.1279 & 0.1365 & 0.1264 & 0.1302 & 0.1289 & 0.1225 & 0.1229 & 0.1072 & 0.1116 & 0.1166 & 0.1127 & 0.1174 & 40.1134 & 40.1131 & 10.1166 & 60.1148 & 80.1173 & 30.1168 & 80.1174 & & & & & & & & \\
\hline KT267185.1 & Gastrocotyle sp. & 0.1739 & 90.0938 & 0.1019 & 0.0880 & 0.0947 & 0.0948 & 0.0881 & 0.0862 & 0.0608 & 0.0492 & 20.0737 & 0.0461 & 0.0788 & 0.0834 & 40.0749 & 90.0749 & 90.0852 & 20.0789 & 90.0808 & 80.0918 & 80.1171 & & & & & & & \\
\hline KT267181.1 & M. formionis & 0.1777 & 70.1011 & 0.1026 & 0.0860 & 0.0907 & 0.0902 & 0.0875 & 0.0867 & 0.0614 & 0.0535 & 0.0713 & 0.0503 & 0.0727 & 70.0808 & 0.0724 & 40.0776 & 60.0808 & 80.0819 & 90.0759 & 90.0912 & 20.1188 & 80.0431 & & & & & & \\
\hline KY640614.1 & P. hemiculteri & 0.1824 & 40.1015 & 0.1088 & 0.1022 & 0.1071 & 0.1059 & 0.0984 & 0.0988 & 0.0823 & 0.0848 & 0.0947 & 0.0836 & 60.0936 & 60.0891 & 0.0927 & 70.0946 & 60.0891 & 10.0565 & 50.0943 & 30.1027 & 70.1313 & 30.0896 & 60.0913 & & & & & \\
\hline AJ228790.1 & P. gurnardi & 0.1706 & 60.0940 & 0.1029 & 0.0898 & 0.0923 & 0.0918 & 0.0883 & 0.0862 & 0.0672 & 0.0731 & 0.0720 & 0.0757 & 0.0740 & 0.0714 & 40.0694 & 40.0739 & 90.0701 & 10.0877 & 70.0773 & 30.0785 & 50.1153 & 30.0783 & 30.0783 & 0.0986 & & & & \\
\hline KP796244.1 & P. pacificum & 0.2068 & 80.1266 & 0.1364 & 0.1217 & 0.1262 & 0.1249 & 0.1198 & 0.1169 & 0.1059 & 0.1081 & 0.1132 & 20.1080 & 0.1140 & 0.1099 & 0.1091 & 10.1125 & 50.1126 & 60.1145 & 50.1127 & 70.1139 & 90.0139 & 90.1110 & 00.1120 & 0.1296 & 0.1165 & & & \\
\hline KP796243.1 & P. pacificum & 0.2068 & 80.1266 & 0.1364 & 0.1217 & 0.1262 & 0.1249 & 0.1198 & 0.1169 & 0.1059 & 0.1081 & 0.1132 & 20.1080 & 0.1140 & 0.1099 & 0.1091 & 0.1125 & 50.1126 & 60.1145 & 50.1127 & 70.1139 & 90.0139 & 90.1110 & 00.1120 & 0.1296 & 0.1165 & 0.0000 & & \\
\hline KP796242.1 & P. pacificum & 0.2068 & 80.1266 & 0.1364 & 0.1217 & 0.1262 & 0.1249 & 0.1198 & 0.1169 & 0.1059 & 0.1081 & 0.1132 & 20.1080 & 0.1140 & 0.1099 & 0.1091 & 10.1125 & 50.1126 & 60.1145 & 50.1127 & 70.1139 & 90.0139 & 90.1110 & 00.1120 & 0.1296 & 0.1165 & 0.0000 & 0.0000 & \\
\hline AJ228791.1 & P. taeniurae & 0.2130 & 0.1316 & 0.1378 & 0.1394 & 0.1384 & 0.1385 & 0.1346 & 0.1320 & 0.1201 & 0.1180 & 0.1203 & 0.1213 & 30.1205 & 0.1221 & 10.1200 & 0.1263 & 30.1233 & 30.1250 & 00.1199 & 90.1267 & 70.0997 & 70.1281 & 10.1339 & 0.1366 & 0.1223 & 0.1050 & 0.1050 & 0.1050 \\
\hline
\end{tabular}




\section{Morsy et al.}
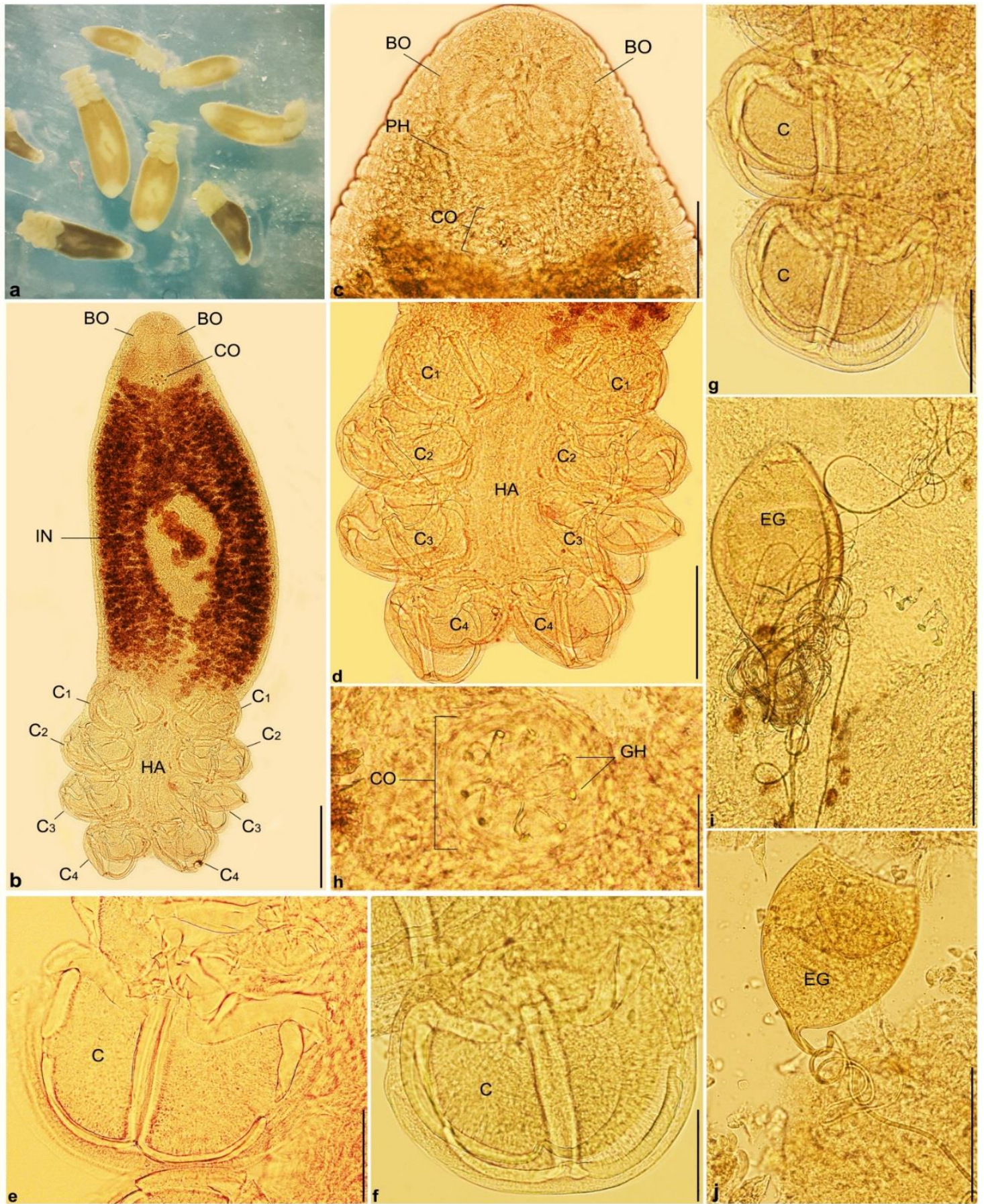

Figure 1. Photomicrographs of $H$. lamothei from Lagocephalus sceleratus off the Arabian Gulf. (a) A paragraph showing the freshly isolated worms from the host gills, (b) Whole-mount of a paratype adult specimen, dorsal view, BO buccal organ, HA haptor, IN intestinal caeca, C clamps, CO copulatory organ, (c) Anterior end of the body, PH pharynx, (d) Haptor (HA) with clamps (C), (e) Anterior clamp, (f) Posterior clamp, (g) Median clamps, (h) Copulatory organ (CO) armed with genital hooks $(\mathrm{GH}),(\mathrm{i}, \mathrm{j})$ Operculated eggs (EG). Scale bars: $b=500 \mu \mathrm{m} ; \mathrm{c}=130 \mu \mathrm{m} ; \mathrm{d}=80 \mu \mathrm{m}$; e = $100 \mu \mathrm{m} ; \mathrm{f}, \mathrm{g}=95 \mu \mathrm{m} ; \mathrm{h}=20$ $\mu \mathrm{m} ; \mathrm{i}=40 \mu \mathrm{m} ; \mathrm{j}=50 \mu \mathrm{m}$. 


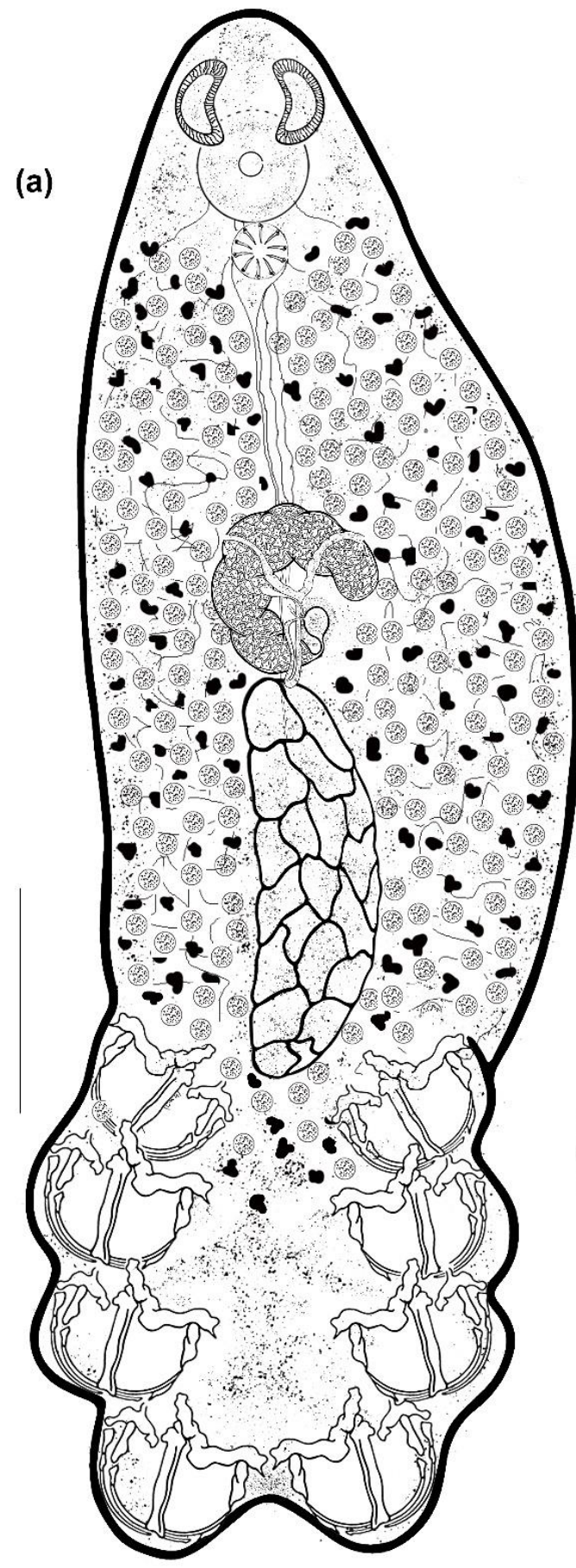

(b)

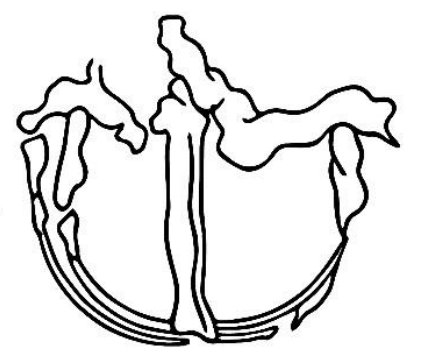

(c)
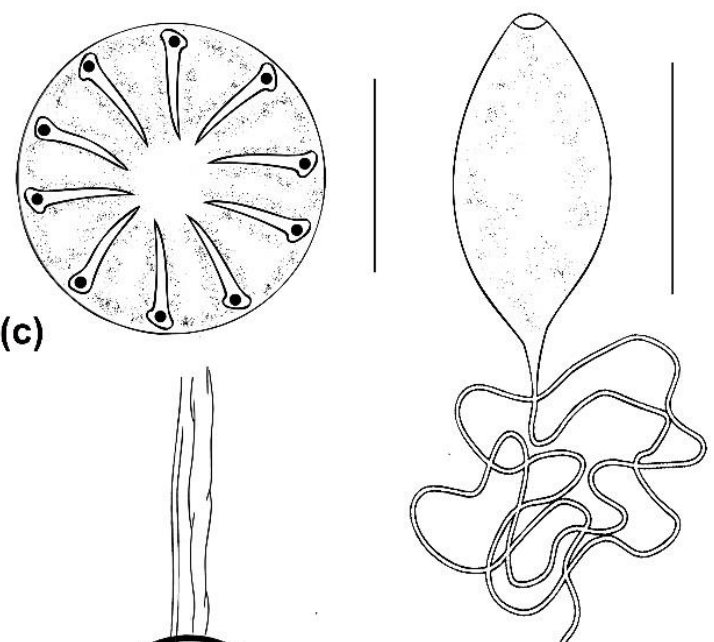

(e)

Figure 2. H. lamothei, (a) Total view, (b) Clamp, isolated median jaw, dorsal view, (c) Armed copulatory organ, (d) Reproductive system, (e) Egg. Scale bars: $\mathrm{a}=400 \mu \mathrm{m} ; \mathrm{b}=20 \mu \mathrm{m}$; $\mathrm{c}=45 \mu \mathrm{m} ; \mathrm{d}=117 \mu \mathrm{m}$; $\mathrm{e}=$ $150 \mu \mathrm{m}$. 

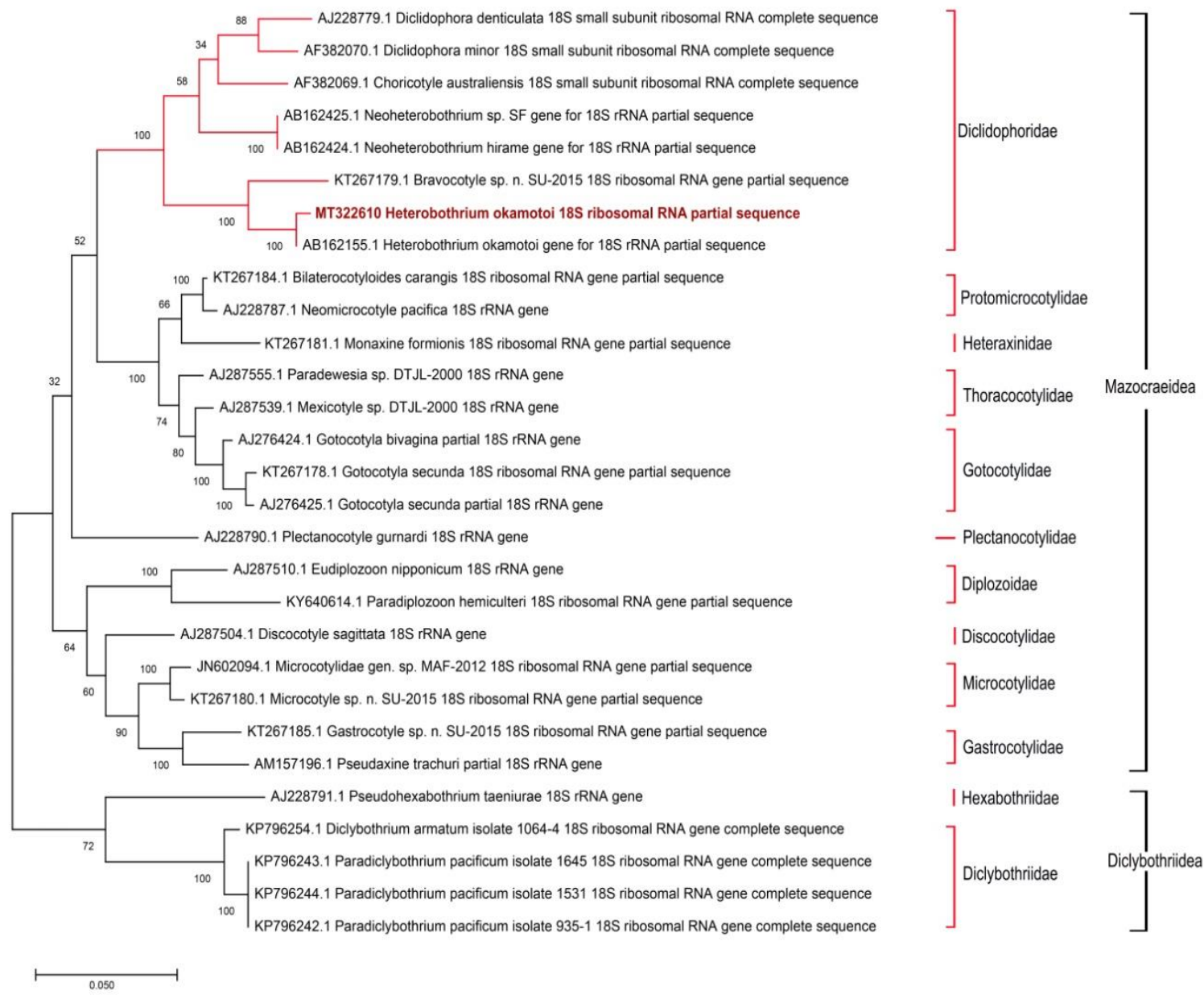

Figure 3. Phylogenetic tree constructed with the maximum likelihood method and Tamura 3-parameter model. The analysis involved 29 nucleotide sequences. The percentage of trees in which the associated taxa clustered together is shown next to the branches. The tree is drawn to scale, with branch lengths measured in the number of substitutions per site. All positions containing gaps and missing data were eliminated. There were a total of 1750 positions in the final dataset. Evolutionary analyses were conducted in MEGA7.

Type-host: Tiger puffer fish Lagocephalus sceleratus (Tetraodontidae).

Type-locality: Coasts of Arabian Gulf at Jubail $\left(26.9598^{\circ} \mathrm{N}, 49.5687^{\circ} \mathrm{E}\right)$, Saudi Arabia.

Site of infection: Gills.

Voucher material: Eleven specimens: 6 holotype and 5 paratypes (acc. no. KKU. BIO20.1-11) deposited in the parasite collection of the parasites section, Biology department museum, College of Science, King Khalid University, Saudi Arabia.

Infection details: Of the seventeen caught fishes, nine were infected by monogeneans, each parasitized by $2-5$ (mean $3 \pm 1$ ) worms.
Etymology: the generic name of the parasite is derived from the presence of anterior most pair of skeletons orientated inversely while the specific name of the parasite is derived from the specific name of the fish where the parasite was recorded for the first time.

\section{DISCUSSION}

Fifteen species of Heterobothrium are currently recognized worldwide: $H$. minimum Sproston (1916), H. affinis Linton (1898), H. ecuadori Meserve (1938), H. galapagense Meserve (1938), H. elongatum Williams (1986), $H$. tetrodonis Goto (1894), H. tonkinense Bychowsky et al. (1976), H. torquigeneri Williams (1986), H. praeorchis Bychowsky et 


\section{Morphology and molecular...}

al. (1976), H. exilis Mamaev (1987),

H. okamotoi Ogawa and Inouye (1991),

H. shinagawai Ogawa and Inouye (1991),

$H$. yamagutii Ogawa and Inouye (1991),

H. bychowskyi Ogawa and Inouye (1991), and

$H$. lamothei Vidal-Martinez and MendozaFranco (2008). Several research papers have been published recently on Heterobothrium spp. such as those of Igarashi et al. (2017) and Matsui et al. (2020), who concluded that these parasites represent a serious problem for the aquaculture of puffer fish. Morphologically, the recorded parasite in the present study belongs to the genus Heterobothrium according to the key published by Llewellyn (1941); it is a polyopisthocotylean parasite with a penis armed with a coronet of pointed hooks, 8-15 in number, testes posterior to the ovary with no vagina, and skeletons of the anterior most pair of posterior suckers orientated inversely in comparison with those of the other three posterior pairs. Generally, polyopisthocotylean monogenean classification is mainly based on the clamp structure, copulatory organ, number and location of testes (Llewellyn, 1941). The present parasite resembles $H$. ecuadori Meserve (1938), $H$. okamotoi Ogawa and Inouye (1991) and $H$. yamagutii Ogawa and Inouye (1991) in their general appearance; however, H. ecuadori differs from it by having a smaller copulatory organ (80-95) armed with 12-15 genital hooks, arranged in a circle, comparable to (114-116) armed with 9-11 hooks in $H$. ecuadori. Additionally, the number of testes of $H$. ecuadori $(27-40)$ varies from the parasite assessed in this study, which was 23-30. H. okamotoi has been found to be a problem for Japanese aquaculture of the puffer fish Takifugu spp., it is morphologically different from the present species; it is longer (45-67.7), with a haptor separated from the body proper by a slender isthmus. The number of testes is relatively similar to that of $H$. yamagutii Ogawa and Inouye (1991), but this parasite has a copulatory organ armed with 10 genital hooks, and has clamps that are similar but longer in size (740014,400) than the parasite recorded herein. $H$. lamothei isolated from the gills of the checkered puffer fish Sphoeroides testudineus off México by Vidal-Martinez and Mendoza-Franco (2008) which is the most morphologically similar species to the present parasite: both have a posterior sucker equipped by clamps with no isthmus, copulatory organ consisting of muscular subspherical cup armed with 12 to 15 genital hooks arranged in a circle, number and dimensions of testes as well as size shape of the ovary are also similar. The degree of variation in the morphology between the present parasite and other monogenean species should be supported by molecular studies to justify the taxonomy of this species (Tambireddy et al. 2016). Construction of phylogenetic trees is important for monogenean taxonomy through the expression of 28s rRNA, which is known to allow better phylogenetic resolution among monogenean families (Mollaret et al., 2000; Tambireddy et al., 2016). The sequence alignment and phylogenetic tree in the present study showed that the position of family Diclidophoridae is unambiguous and constructed in a separate clade. Similar observations have been reported in previous studies concerning the partial 28s rRNA of parasitic monogeneans (Mollaret et al., 2000; Tambireddy et al., 2016). Additionally, the current sequence analysis showed that the partial 28s rRNA gene has a sufficient phylogenetic signal, making it useful for phylogenetic tree reconstruction in accordance with Tambireddy et al. (2016). Since that the percentage of sequence identities between the present parasite and the aligned sequences showed a maximum identity of $89.09 \%$ with $H$. okamotoi which is morphologically different, the recorded parasite cannot be assigned to any of the aligned sequences. The parasite is mostly similar to $H$. lamothei which was not phylogenetically analyzed before. Thus, the present study should be considered as the first molecular study analyzing 28s rRNA gene of $H$. lamothei isolated from the tiger puffer fish Lagocephalus sceleratus (Tetraodontidae).

\section{CONCLUSION}

The present study is the first to provide morphological description as well as molecular analysis of the partial sequences of the $28 \mathrm{~S}$ rDNA of $H$. lamothei from the tetraodontid $L$. sceleratus from the coasts of Arabian Gulf at Jubail, Saudi Arabia which is included in the establishment of a data base for the genus that will aid future studies and species circumscription. The results obtained from molecular analysis are consistent with the conclusions drawn from morphological classification. Detailed studies relating the morphology of attachment organs have provided valuable data on the mechanical processes accounting for the high host specificity of species and deserve further attention. We also 
suggest that future studies studying in vivo morphological and physiological changes during the development of monogeneans attached on unusual hosts, especially with phylogenetically close host species, are needed.

\section{ACKNOWLEDGMENT}

This work was supported by Taif University Researchers Supporting Project number (TURSP-2020/299), Taif University, Taif, Saudi Arabia. Also, The authors extend their appreciation to the Deanship of Scientific Research at King Khalid University for funding this work through General Research Project under grant number (G.R.P-120-39).

\section{REFERENCES}

AGRAWAL, N.; TRIPATHI, A.; DEVAK A. Monogeneans from the gills of glass fishes (Teleostei: Oerciformes: Ambassidae) in India, with the proposal of Chandacleidus n.g. (Monogenea: Dactylogyridae). Syst. Parasitol., v.63, p.221-228, 2006.

BOEGER, W.A.; KRITSKY, D.C. Phylogenetic relationships of the Monogenoidea. In: LITTLEWOOD, D.T.J.; BRAY, R.A. (Eds.). Interrelationships of the platyhelminthes. London: Taylor \& Francis, 2001. p.92-102.

BYCHOWSKY, B.E.; MAMAEV-YU L.; NAGIBINA L.F. Revision of the genus Heterobothrium Cerfontaine, 1895 (Diclidophoridae). Trudy-BiologoPochvennogo-Instituta- Issledovaniyamonogenticheskikh-sosal'shchikov. Seriya: Novaya, 1976. p.29-40.

CERFONTAINE, P. Note sur les Diclidophorinae (Cerf.) et description d'une nouvelle espece Diclidophora labracis (Cerf.). Bull. Acad. Belg., v.30, p.125-150, 1895.

DESDEVISES, Y.; MORAND, S.; LEGENDRE, P. Evolution and determinants of host specificity in the genus Lamellodiscus (Monogenea). Biol. J. Linn. Soc., v.77, p.431-443, 2002.

ERGENS, R. The suitability of ammonium picrate glycerin in preparing slides of lower Monogenoidea. Folia Parasitol., v.16, p.320, 1969.
GARCÍA-VÁSQUEZ, A.; RAZO-MENDIVIL, U.; RUBIO-GODOY, M. Morphological and molecular description of eight new species of Gyrodactylus von Nordmann, 1832 (Platyhelminthes: Monogenea) from poeciliid fishes, collected in their natural distribution range in the Gulf of Mexico slope, Mexico. Parasitol. Res., v.114, p.3337-3355, 2015.

GOTO, S. Studies on the ectoparasitic trematodes of Japan. J. Coll. Sci. Imp. Univ., v.8, p.1-273, 1894

IGARASHI, K.; MATSUNAGA, R.; HIRAKAWA, S. et al. Mucosal IgM antibody with d-mannose affinity in fugu Takifugu rubripes is utilized by a monogenean parasite Heterobothrium okamotoi for host recognition. J. Immunol., v.198, p.4107-4114, 2017.

JUSTINE, J.L.; LAMBERT, A.; MATTEI, X. Spermatozoon ultrastructure and phylogenetic relationships in the monogeneans (Platyhelminthes). Int. J. Parasitol., v.15, p.601608, 1985.

LINTON, E. Notes on trematode parasites of fishes. Proc. Nat. Mus., v.20, p.507-548, 1898.

LLEWELLYN, J. A description of the anatomy of the mono genetic trematode Choricotyle chrysophryi Van Beneden \& Hesse, 1863. Parasitology, v.33, p.397-405, 1941.

MAMAEV, YU. L. On the systematic position of the genus Neoheterobothrium Price, 1943 (Monogenea, Diclidophoridae) in connection with the description of a new species $N$. syacii. Parazitologiya, v.21, p.69-73, 1987.

MATSUI, S.; GOTO T.; TSUBOUCHI; Y. et al. $\mathrm{D}$-mannose-specific Immunoglobulin $\mathrm{M}$ in Grass Puffer (Takifugu niphobles), a Non host Fish of a Monogenean Ectoparasite Heterobothrium okamotoi, Can Act as a Trigger for its Parasitism. J. Parasitol., v.106, p.276-282, 2020.

MENDOZA-FRANCO, E.F.; TUN, M.D.C.R.; ANCHEVIDA, A.J.D.; RODRÍGUEZ, R.E.D.R. Morphological and molecular (28S rRNA) data of monogeneans (Platyhelminthes) infecting the gill lamellae of marine fishes in the Campeche Bank, southwest Gulf of Mexico. Zookeys, v.11, p.125-161, 2018.

MESERVE, F.G.C. Some monogenetic trematodes from Galapagos Islands and the neighboring Pacific. Allan Hancock Pacific Exped., v.2, p.31-89, 1938. 
MOHAMMED-GEBA, K.; MAHDY, A.A.; EISSA, A.S.A.; OSMAN, A.G.M. Analysis of population genetics of the Endangered Nile pufferfish Tetraodon lineatus (Linnaeus, 1758) in the Upper Egyptian River Nile. Int. J. Ecotoxicol. Ecobiol., v.1, p.60-66, 2016.

MOLLARET, I.; JAMIESON, B.G.M.; JUSTINE, J.L. Phylogeny of the Monopisthocotylea and Polyopisthocotylea (Platyhelminthes) inferred from 28S rDNA sequences. Int. J. Parasitol., v.30, p.171-185, 2000.

NAGIBINA, L.F. Heterobothrium affinis (Linton) and its position in the system of monogenetic trematodes of the family Diclidophoridae Fuhrmann. Trudy. Zool. Inst. Akad. Nauk., v.13, p.137-144, 1953.

NAKANE, M.; OGAWA K.; FUJITA T. et al. Acquired protection of tiger puffer Takifugu rubripes against infection with Heterobothrium okamotoi (Monogenea: Diclidophoridae). Fish Pathol., v.40, p.95-101, 2005.

NAKAYASU, C.; YOSHINAGA, T.; KUMAGAI, A. Hemato logical characterization of anemia recently prevailing in wild Japanese flounder in Japan. Fish Pathol., v.37, p.38-40, 2002.

OGAWA, K. Redescription of Heterobothrium tetrodonis Goto (1894) (Monogenea: Diclidophoridae) and other related new species from puffers of the genus Takifugu (Teleostei: Tetraodontidae). Jap. J. Parasitol., v.40, p.388396, 1997.

OGAWA, K.; INOUYE, K. Heterobothrium infection of cultured tiger puffer, Takifugu rubripes, infection experiments. Fish Pathol., v.32, p.21-27, 1991.

PANDEY, K.C.; AGARWAL, N. An encyclopaedia of Indian monogenoidea. New Delhi: Vitasta Publishing, 2008. 530p.
RANDALL, J.E. Coastal fishes of Oman. Australia: Crawford House Publishing Pty Ltd Bathurst. 1995. 439p.

ROHDE, K. Gill Monogenea of deepwater and surface fish in southeastern Australia. Hydrobiologia, v.160, p.271-283, 1988.

SCOTLAND, R.W.; OLMSTEAD R.G.; BENNETT J.R. Phylogeny reconstruction: the role of morphology. Syst. Biol., v.52, p.539-548, 2003.

ŠIMKOVA, A.; VERNEAU, O.; GELNAR, M.; MORAND, S. Specificity and specialization of congeneric monogeneans parasitizing cyprinid fish. Evolution, v.60, p.1023-1037, 2006.

SPROSTON, N.G. A synopsis of monogenetic trematodes. Trans. Zool. Soc. Lond., v.25, p.185600, 1916.

SPROSTON, N.G. Synopsis of the monogenetic trematodes. Trans. Zool. Soc. Lond., v.25, p.185600, 1946.

TAMBIREDDY, N.; GAYATRI, T.; GIREESHBABU; P., PAVAN-KUMAR, A. Molecular characterization and phylogeny of some mazocraeidean monogeneans from carangid fish. Acta Parasitol., v.61, p.360-368, 2016.

VIDAL-MARTÍNEZ, V.M.; MENDOZAFRANCO, E.F. Heterobothrium lamothei n. sp. (Monogenea: Diclidophoridae) from the gills of Sphoeroides testudineus (Pisces: Tetraodontidae) from the coast of Yucatán, Mexico. Rev. Mex. Biodiv., v.79, p.89S-93S, 2008.

WILLIAMS, A. Taxonomy of two new species of Heterobothrium (Monogenea: Diclidophoridae) from Torquigener pleurogramma (Pisces: Tetraodontidae) from Western Australia. Aust. J. Zool., v.34, p.707715, 1986.

YOSHINAGA, T.; KAMAISHI, T.; SEGAWA, I. et al. Anemia caused by challenges with the monogenean Neoheterobothrium hirame in the Japanese flounder. Fish Pathol., v.36, p.13-20, 2001. 